\title{
Application of Value Clarification Technique (Vct) Models in Improving Learning Outcomes in Dangerous Goods Regulation
}

\author{
Ariyono Setiawan*, Luthfiyah Nurlaela, Meini Sondang, Eppy Yundra \\ Vocational Education, Universitas Negeri Surabaya \\ *Corresponding author, e-mail: ariyono.19010@mhs.unesa.ac.id
}

\begin{abstract}
Learning in school or in every educational institution has an important role as a media liaison between knowledge and students or students. There are many learning methods or models used in education. Of the many methods or modes, there is one of them is a clarification value technology (VCT) model. The teaching method is a knowledge of teaching methods used by a teacher or instructor. Another understanding is the presentation technique mastered by the teacher to teach or present learning materials to students in class both individually and in groups. the learning method by clarifying the value of the value clarification technique is teaching to shape students in finding and determining a value that is considered good in dealing with a problem through the process of analyzing existing values and embedded in students. Meanwhile, learning outcomes are abilities students have after they have a learning experience. The purpose of this study is to determine the level of learning outcomes of a particular institution. In this study the object of research from an educational institution that is competent in the field of flight is used. The institution is Surabaya Aviation Polytechnic. The subject of learning taken was Regulation of Dangerous Goods at Surabaya Aviation Polytechnic. In addition, this study was also conducted to determine differences in learning outcomes of cadets in the Lessons on Dangerous Goods Regulations in Surabaya Aviation using the Value Clarification Technique (VCT) method. This type of research is Classroom Action Research (CAR). The research carried out is included in the design of one group pretest and possttest research. the research design that contained pretest before being given treatment and posttest after being treated. This research was conducted at Surabaya Aviation Polytechnic. The data analysis technique used is the different test. Based on data management and analysis results, it can be concluded that the application of learning of Value Clarification Techniques can improve the learning outcomes of cadets. This is evidenced by the differences in learning outcomes of Cycle I and Cycle II significantly.
\end{abstract}

Keywords: dangerous goods regulations, learning model value clarification technique, youth learning outcomes

How to Cite: Setiawan, A., Nurlela, L., Sondang, M., \& Yundra, E. (2020). Development of learning devices of basic electronic virtual laboratory based on PSPICE software. Journal of Vocational Education Studies, 3(2), 1-12. DOI: https://doi.org/10.12928/joves.v3i2.2482.

\section{INTRODUCTION}

Learning is a process of change that is the change in behavior as a result of interaction with the environment in meeting their needs. These changes will be evident in all aspects of behavior (Slameto, 2015). The learning process occurs because of a goal to be achieved. The intended purpose is in the form of learning outcomes. Learning outcomes must show a change in behavior that is permanent, functional, positive and conscious. The realization of learning outcomes will always be related to evaluation activities. For this reason, learning techniques and evaluation procedures are needed that can effectively assess the learning process and outcomes.

The learning model is one of the important components in learning. An effective learning model will be very helpful in the learning process, so that learning objectives will be more easily achieved. One of the goals of learning in the learning process is the achievement of high taruna learning outcomes. Learning outcomes show the actual ability 
of tarunas who have experienced the process of transferring knowledge from someone who can be said to be an adult or have insufficient knowledge. So, with the learning outcomes, people can find out how far students can capture, understand, has certain subject matter. On that basis educators can determine better teaching and learning strategies (Purwanto, 2010).

But in reality, it is known that there are low student learning outcomes. This is what makes the learning process goes one way because students are not included during the teaching and learning process. Methods like this result in a less effective learning process. One effective learning method as an alternative is the value clarification technique (VCT) learning method. The learning method by clarifying the value of the value clarification technique (VCT) is teaching to shape students in finding and determining a value that is considered good in dealing with a problem through the process of analyzing existing values and embedded in students (Wina Sanjaya, 2006: 34) .

As for one of the advantages of using the VCT learning method is being able to clarify/explore and express the contents of the message the material delivered will then make it easier for teachers to convey meaning/message values/morals. The VCT approach is a value education approach in which students are given the freedom to determine their own values based on what they have received in their environment. According to Steeman in Adisusilo, (2012) value is something that is the source of meaning in life, which gives a reference, starting point and purpose in life. In this VCT approach students are not asked to memorize the values that have been chosen by other parties. But rather, helped to find, analyze, account for, develop, choose, take a stand, and practice the values of his own life (Adisusilo, 2012).

The use of the VCT approach is expected to be able to increase student learning activities to understand learning material so that it will improve student learning outcomes. This has been proven by Novianty and Monisa (2017) where in her research it was proved that the Learning Method of Value Clarification Technique (VCT) with the classroom action research method carried out by two cycles, apparently showed that there was an increase in student learning outcomes. The same finding was also proven by Risvanelli (2017) who found that student learning outcomes using the VCT approach experienced a significant increase.Likewise Sutaryanto (2015) in his research proved that learning outcomes using the documentary film-assisted VCT model have better abilities than learning outcomes in the control class with conventional learning. The application of the Value Clarification technique (VCT) model aided by documentary films in instilling the value of nationalism can work effectively

\section{RESEARCH METHOD Learning Methods}

Learning is something done by students, not made by students. Learning is basically an educational effort to help students carry out learning activities (Isjoni, 2010). Joyce and Weil in Rusman (2012) argue that the learning model is a plan or pattern that can be used to shape the curriculum (long-term learning plan), design learning materials, and guide learning in class or other.

The teaching method is a knowledge of teaching methods used by a teacher or instructor. Another understanding is the presentation technique mastered by the teacher to teach or present learning materials to students in class both individually and in groups (Ahmadi and Prasetyo, 2005). Roestiyah (2012) explains that teaching methods can be interpreted as teacher techniques for teaching or presenting learning material to students in class, so that the lesson can be captured, understood, and used by students well.

Application of Value Clarification Technique (Vct) Models in Improving Learning Outcomes in 


\section{Learning Model Value Clarification Technique}

VCT is a method of instilling values that refers to the value approach in such a way that students get clarity / stability of values. Masnu Muslih (2010) defines that the value clarification technique places an emphasis on helping students to assess their own feelings and actions, to increase their awareness of their own values. Another opinion expressed by Sanjaya (2010) which states that the learning method by clarifying the value of the value clarification technique is teaching to shape students in finding and determining a value that is considered good in dealing with a problem through the process of analyzing existing values and embedded in students, VCT as a method in moral learning strategies VCT aims to (Sanjaya, 2010):

1. To measure or know the level of student awareness about a value

2. Fostering student awareness about the values they have both the level and nature (positive and negative) to then be fostered towards improvement and correction

3. To instill certain values in students through rational and accepted ways by students, so that ultimately these values will belong to students

4. Train students how to assess, accept, and make decisions on a problem in relation to daily life in the community

\section{Learning Outcomes}

Learning outcomes are changes in behavior in a person that can be observed and measured forms of knowledge, attitudes and skills. These changes can be interpreted as an increase and development that is better than before and do not know to know (Hamalik, 2011). Sudjana (2009) explains that learning outcomes are abilities students possess after they have a learning experience. Whereas Supridjono (2013) defines learning outcomes as meanings, attitudes, appreciation, and skills.

Kingsley in Sudjana (2009) divides three kinds of learning outcomes, namely (a) skills and habits, (b) knowledge and understanding, (c) attitudes and ideals. Each type of learning outcomes can be filled with materials that have been specified in the curriculum. Sudjana (2009) further classifies that learning outcomes are patterns of actions, values, understandings, attitudes, appreciation and skills in the form of:

1. Verbal information, namely the ability to express knowledge in the form of language, both oral and written

2. Intellectual skills, namely the ability to present concepts and symbols or the ability to carry out cognitive activities are unique

3. Cognitive strategies, namely the ability to channel and direct their own cognitive activities

4. Motor skills, namely the ability to do a series of physical movements

5. Attitude is the ability to internalize and externalize values

\section{Types of Research}

This type of research is Classroom Action Research (CAR). According to Arikunto (2008) classroom action research is action research conducted in class with the aim of improving/improving the quality of learning practices. This cycle does not only last one cycle but several times to achieve the expected goals.

The research design used in this study was "One Groups Pretest-Posttest Design", the research design that contained pretest before being given treatment and posttest after being treated. Thus it can be known more accurately, because it can be compared with held before being given treatment (Sugiyono, 2016). The form of this design is as follows.

$01 \quad \mathrm{X} \quad 02$


Information:

Figure 1. One Group Pretest Possttest Design

01 : prep post

$\mathrm{X}$ : treatment

02 : post test

\section{Research Subject}

The subject chosen for research in this study was the Surabaya Aviation Polytechnic taruna, which is 24 tarunas. The object chosen in this study is the use of the value clarification technique learning method to improve student learning outcomes in the Dangerous Goods Regulations course at Surabaya Aviation Polytechnic.

\section{Research Procedure}

The research design used in this study uses the Kemmis and Mc Taggart research designs which are the development of the Kurt Lewin model. In its planning, Kemmis uses a spiral system of self-reflection that starts with planning, acting, observing, reflecting and replanning which is the basis for a square of problem solving. The basic pattern of the CAR model according to Kemmis and Mc. Taggart as follows.

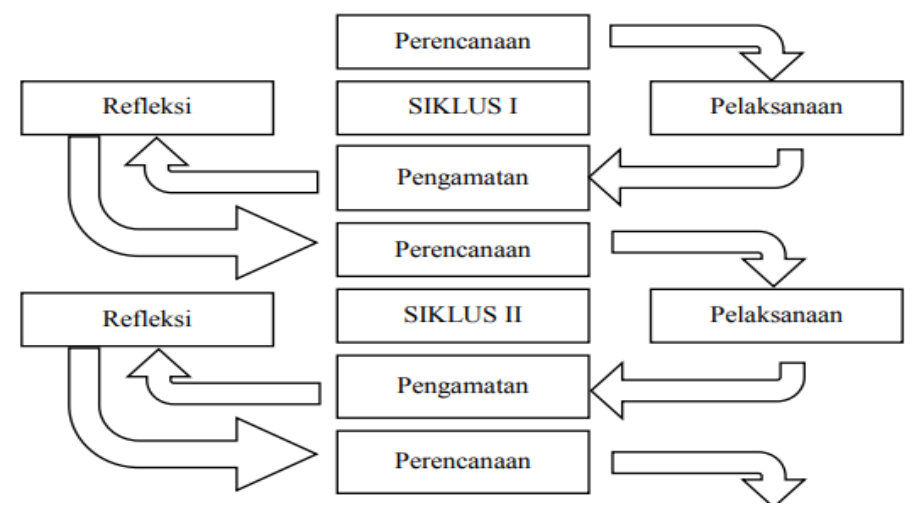

Figure 2. The flow of the implementation of Classroom Action Research from Kemmis and Mc. Taggart (Source: Arikunto, 2010: 137)

Based on this picture, there are cycles that have four important components in each cycle consisting of planning (plan), implementation (action), observation (observe), and reflection (reflect). These components will continue to rotate sequentially from cycle I to cycle II and will continue to rotate towards the next cycle until the desired goal can be achieved. The stages of Class Action in this study are as follows:

\section{Planning}

At this planning stage, researchers together with collaborators will determine alternative actions to be taken in an effort to improve the skills of the desired subjects through several stages below.

a. Determine the subject or material to be provided.

b. Develop a lesson plan (RPP).

c. Prepare learning media that will be used in learning.

d. Prepare research instruments in the form of tests, observation guidelines, field notes, questionnaires, interview guidelines, and documentation tools. 
e. Develop an evaluation format.

\section{Implementation of Actions}

Implementation of actions, namely implementing KBM in accordance with RPP cycle I that has been made in collaboration with collaborators. The core of the implementation is learning the Dangerous Goods Regulations course with the value clarification technique learning method in improving the learning outcomes of tarunas.

\section{Observation}

Observations are made based on the activities that have been carried out. The activities carried out are reflected in the observation sheets and field notes. The success of the learning process is marked by a change in the tarunas' positive attitude. The success of the method is based on the success of tarunas in explaining a number of things in the Dangerous Goods Regulations course, which is indicated by an increase in the ability score of tarunas.

\section{Reflection}

The researcher and collaborator, the lecturer of the Dangerous Goods Regulations course, conducted an analysis and interpreted the results of the treatment in the first cycle. Then based on the results of the reflection, if there were unsuccessful and less than optimal aspects, the second cycle was carried out using the value clarification technique learning method.

\section{Data Collection Techniques}

The researcher is an instrument because the researcher is both a planner, executor, data collector, analyzer, interpreter of data and ultimately becomes a research reporter (Moleong, 2013: 168). The retrieval of data using:

\section{Observation}

In this study the observation sheet was used in the value clarification technique learning model, namely the student learning outcomes sheet. The observation sheet of the implementation of learning is used as a guideline for researchers in observing the implementation of learning the value clarification technique learning model.

\section{Test}

In the learning model, the value clarification technique uses tests in the form of written test sheets. This test is used to determine the extent to which students' understanding of the material in the Dangerous Goods Regulations course.

\section{Documentation}

The documentation used in this study is a syllabus, lesson plans, and student grades, teacher documents regarding student grades, and photographs during the learning process.

\section{Data Analysis Technique}

The data analysis technique used is descriptive analysis. Descriptive research is research conducted to determine the existence of an independent variable, either only on one or more variables without making comparisons or connecting with other variables the independent variable is a stand-alone variable, not an independent variable, because if the independent variable is always paired with the dependent variable (Sugiyono, 2016).

\section{ANALYSIS AND DISCUSSION}




\section{Dangerous Goods Regulations Restrictions Material}

Based on IATA regulations, there are several basic rules that limit or require a variety of dangerous goods which can or cannot be transported by airplane based on the characteristics of the goods and other provisions. Dangerous goods which are prohibited in any condition, as follows:

a. Explosives (explosives) that can burn in temperatures of 750C within 48 hours

b. Explosives containing chlorine and ammunium salts

c. Explosives containing a mixture of clorats and phosphorus

d. Classified explosives are very sensitive to mechanical materials.

e. Liquid explosives that are classified as quite sensitive to mechanical materials.

f. Substances or substances which can be dangerous due to the presence of gas or heat under certain conditions.

g. Flammable substances or substances and organic peroxides which are classified as having additional risk (subsidiary risk).

h. Substances or substances listed in the List of DGR Subsection 4.2

The subjects of this study were Surabaya Aviation Polytechnic tarunas. Research results are described in detail based on planning, implementing actions, observing, and reflecting. The results of the study will be presented in tabular form. The criterion for success in the Dangerous Goods Regulations course using the value clarification technique learning media is that there is an increase associated with taruna activities, especially the mastery of Dangerous Goods Regulations limiting material. This is indicated by an increase in the rating scale of each cycle / treatment carried out in a better direction. In addition, the indicator of success is seen from the indicator of the success of the process, namely an increase in the activeness of tarunas in learning.

Evaluation of learning conducted at Surabaya Aviation Polytechnic, where is the evaluation of learning conducted research in class. Dangerous Goods Regulations courses. In the implementation of this learning evaluation consists of 2 cycles, where in the first cycle was held on Monday, April 2020 at 07.00 - 08.10, while the second cycle was held on Friday, April 2020 8: 10-09: 15.

\section{Cycle I Research Results}

1. Planning

At this stage, researchers and collaborators plan the action procedures to be taken to improve the understanding of tarunas (subjects). This planning starts from planning learning strategies, organizing class and time, evaluating, and documenting. Furthermore, researchers and collaborators equate perceptions and discuss to identify problems that arise in learning while finding solutions to those problems. Researchers and lecturers as collaborators also prepare learning scenarios and compile the final test of cycle I.

2. Implementation

Implementation or Actions in the first cycle carried out for 80 minutes. At this stage, researchers and collaborators determine actions according to the planning that has been done to improve the subject's skills. At this meeting the lecturer explained the principles of the learning model of Dangerous Goods Regulations with conventional media which must be mastered by tarunas in accordance with the RPP and syllabus. Learning ends with the lecturer giving a conclusion about learning.

3. Observation

Researchers and collaborators make observations and evaluations of the course of the implementation of these actions. The results obtained include the results of actions on

Application of Value Clarification Technique (Vct) Models in Improving Learning Outcomes in 
the learning process (process success) and the impact on learning outcomes (product success).

a. Success of Process

The success of the process can be seen from the situation of tarunas who play a more active role in learning by expressing opinions, the enthusiasm of tarunas who are starting to emerge, and learning that seems livelier and more enjoyable, although not too many have commented.

b. Product success

From the results of the implementation of the actions taken in the first cycle obtained data in the form of taruna test results below.

Table 1. Taruna Test Score Results in Cycle I

\begin{tabular}{cc}
\hline No. & $\begin{array}{c}\text { Score } \\
\text { Cycle } 1\end{array}$ \\
\hline 1 & 85 \\
2 & 60 \\
3 & 75 \\
4 & 85 \\
5 & 85 \\
6 & 75 \\
7 & 65 \\
8 & 80 \\
9 & 85 \\
10 & 65 \\
11 & 75 \\
12 & 85 \\
13 & 75 \\
14 & 85 \\
15 & 70 \\
16 & 70 \\
17 & 85 \\
18 & 75 \\
19 & 70 \\
20 & 70 \\
21 & 75 \\
22 & 65 \\
23 & 80 \\
24 & 85 \\
Align & 76.04 \\
\hline
\end{tabular}

Based on the results of the data show that the results of the first cycle test has an average value of 76.04. This means that the ability of tarunas to learn Dangerous Goods Regulations with conventional media is quite low. It can be said that the achievement of tarunas is still not satisfactory. Based on observations and analysis, the researcher concludes that students are still confused, lack of understanding in the material being taught. From the results of observations in the first cycle, there are still many shortcomings of students in learning, especially Dangerous Goods Regulations. 
Therefore, it is necessary to plan appropriate learning media in order to improve the quality of understanding tarunas in learning Dangerous Goods Regulations.

4. Reflection

At this stage the researcher and the collaborator conduct the analysis and interpret the results of the action in cycle I.

\section{Cycle II Research Results}

1. Planning

At this stage the researcher and collaborator plan actions in cycle II to improve the understanding of tarunas with the learning media value clarification technique which is considered not optimal in cycle I.

2. Implementation / Action

At this meeting, collaborators begin the lesson with perceptions, learning objectives, and motivations to help tarunas dare to express their opinions. The lecturer reviews the learning material and provides assistance to tarunas who feel they do not understand the learning material. Researchers and collaborators observe the behavior of tarunas, the reaction of tarunas, and the learning atmosphere.

Basically, the method of implementing teaching is the same as the first meeting of the first cycle, it's just that at this meeting lecturers exchange more opinions with tarunas, ask questions about the material and give each other comments on the material being studied. During the learning process, lecturers and researchers continue to observe the behavior of tarunas.

3. Observation

After implementing the learning actions with the learning media value clarification technique in the Learning Dangerous Goods Regulations material, researchers and collaborators make observations and evaluations of the course of the implementation of these actions. The results obtained include the results of actions on the learning process (process success) and the impact on learning outcomes (product success).

a) Success of Process

The success of the process can be seen from tarunas who play a more active role in learning by giving comments to lecturers 'statements and other tarunas' statements, the classroom atmosphere is more conducive, tarunas appear more confident, and learning seems more lively and enjoyable compared to the previous cycle.

b) Product success

From the results of the actions taken in cycle II, the data below are obtained.

Application of Value Clarification Technique (Vct) Models in Improving Learning Outcomes in

Dangerous Goods Regulation

Setiawan, A., Nurlela, L., Sondang, M., \& Yundra, E. 
Table 2. Taruna Test Score Results in Cycle II

\begin{tabular}{cc}
\hline No. & $\begin{array}{c}\text { Score } \\
\text { Cycle } 2\end{array}$ \\
\hline 1 & 95 \\
2 & 70 \\
3 & 85 \\
4 & 90 \\
5 & 90 \\
6 & 85 \\
7 & 80 \\
8 & 85 \\
9 & 90 \\
10 & 80 \\
11 & 85 \\
12 & 90 \\
13 & 85 \\
14 & 90 \\
15 & 80 \\
16 & 85 \\
17 & 90 \\
18 & 85 \\
19 & 85 \\
20 & 90 \\
21 & 85 \\
22 & 80 \\
23 & 85 \\
24 & 90 \\
Align & 85.63 \\
\hline & \\
\hline 1 & \\
23 \\
21
\end{tabular}

After the action was taken, researchers and collaborators found an increase in the ability of tarunas in the Dangerous Goods Regulations and changes in the attitude of tarunas who are positive towards learning. From the results of the scores of each aspect assessed it can be seen the increase in the average value of all students after the cycle II action.

So it can be concluded that the ability and understanding of students has increased. Thus, it can be concluded that the ability of tarunas in the Dangerous Goods Regulations material after the second cycle action has increased by 85.63 . The following is descriptive research data for tarunas learning outcomes:

Table 3. Descriptive Learning Cycle I and Cycle II 


\begin{tabular}{|l|r|r|r|r|r|}
\hline & \multicolumn{1}{|c|}{ Descriptive Statistics } \\
\hline Hasil belajar (Pretest) & 24 & \multicolumn{1}{|c|}{ Minimum } & Maximum & \multicolumn{1}{l|}{ Mean } & Std. Deviation \\
Hasil Belajar (Posttest) & 24 & 70.00 & 85.00 & 76.0417 & 7.93714 \\
Valid N (listwise) & 24 & & 95.00 & 85.6250 & 5.17362 \\
\hline
\end{tabular}

Descriptive calculation results for Cycle I data obtained an average learning outcome of tarunas is 76.04 with a value of data spread of 7.93. The maximum taruna learning achievement value is 85 and the minimum taruna learning achievement value is 60 . While the Cycle II data obtained the average taruna learning outcomes is 85.62 with a data dissemination value of 5.17. The maximum taruna learning achievement value is 95 and the minimum taruna learning achievement value is 70 .

The results showed that there was an influence of the use of the media learning value clarification technique on the learning outcomes of tarunas, this was evidenced by an increase in the learning outcomes of the Cycle in Cycle II. Cycle I and Cycle II learning outcomes have different mean values, where the average learning outcomes of tarunas after utilizing the learning media value clarification technique is greater than the learning outcomes of tarunas before utilizing the learning media value clarification technique. This means that there is a significant increase in the learning outcomes of tarunas after utilizing the media learning value clarification technique.

It is known that the value of learning outcomes of tarunas after using the media learning value clarification technique is increasing, it needs to be understood that the observation activities of learning media value clarification technique tarunas will be more active and enjoyable for the tarunas so that the application of the VCT learning model is expected to make learning more effective. With so activities and learning outcomes of tarunas and teacher performance will be more optimal. According to Djahiri (1985) in Taniredja, Faridli, and Harmianto (2011: 91), VCT has the advantage of affective learning because: a) Able to develop and instill values and morals in the realm of the internal side or the internal side of the tarunas; b) Able to clarify and express the contents of the message material delivered, which further makes it easier for teachers to convey meaning or message values; c) Able to clarify and assess the quality of the taruna's moral values, see the values that exist in others, and understand the moral values that exist in real life; d) Being able to invite, involve, foster, and develop the potential of tarunas especially developing potential attitudes; e) Being able to provide a number of learning experiences from various lives; f) Able to ward off, negate, intervene, and integrate various moral values in the system of values and morals that exist in a person; g) Give a picture of moral values that are acceptable and guide and motivate to live decent and high moral. and understand the moral values that exist in real life; d) Being able to invite, involve, foster, and develop the potential of tarunas especially developing potential attitudes; e) Being able to provide a number of learning experiences from various lives; f) Able to ward off, negate, intervene, and integrate various moral values in the system of values and morals that exist in a person; g) Give a picture of moral values that are acceptable and guide and motivate to live decent and high moral. and understand the moral values that exist in real life; d) Being able to invite, involve, foster, and develop the potential of tarunas especially developing potential attitudes; e) Being able to provide a number of learning experiences from various lives; f) Able to ward off, negate, intervene, and integrate various moral values in the system of values and morals that exist in a person; g) Give a picture of moral values that are acceptable and guide and motivate to live decent and high moral. and integrating various moral values in the system of values and morals that exist in a person; g) Give a picture of moral values that are acceptable and guide and motivate to live decent and high moral. and integrating various

Application of Value Clarification Technique (Vct) Models in Improving Learning Outcomes in Dangerous Goods Regulation Setiawan, A., Nurlela, L., Sondang, M., \& Yundra, E. 
moral values in the system of values and morals that exist in a person; g) Give a picture of moral values that are acceptable and guide and motivate to live decent and high moral.

\section{CONCLUSION}

The conclusion that can be drawn from the results of research conducted in improving the learning outcomes of tarunas in the Dangerous Goods Regulations course is that the application of Value Clarification Technique learning can improve the learning outcomes of tarunas. This is evidenced by the significant differences in learning outcomes in Cycle II. The learning outcomes of tarunas after applying the Value Clarification Technique learning were significantly higher than the learning outcomes of the tarunas before applying the Value Clarification Technique learning in the Dangerous Goods Regulations course.

\section{ACKNOWLEDGEMENT}

Based on the conclusions above, there are several things that must be done by an educator in an effort to assist the taruna in understanding a learning material, which include:

a. It is expected that teachers can continue and develop the learning model of Value Clarification Technique in the Dangerous Goods Regulations course in the next learning process in order to optimize learning outcomes.

b. Researchers can then develop research in an innovative and comprehensive way to overcome the limitations experienced by researchers during the study.

c. Other places of education can develop variations of learning models using Value Clarification Technique learning along with the provision of computers and other educative media for students.

\section{REFERENCES}

Ahmadi, A. dan J. T. Prasetyo. (2005). Startegi Belajar Mengajar. Bandung: Pustaka Setia. Arikunto, S. (2008). Prosedur Penelitian Suatu Pendekatan Praktik. Jakarta: Rineka Karya. Djahiri. (1985). Strategi pengajaran Afektifnilai-moral VCT dan Games dalam VCT, Bandung: Penerbit Granesia.

Elmubarok. Z. (2009). Membumikan Pendidikan Nilai. Bandung: Alfabeta.

Hamalik, O. (2011). Kurikulum dan Pembelajaran. Jakarta: Bumi Aksara.

Isjoni. (2010). Pembelajaran Kooperatif Meningkatkan Kecerdasan Komunikasi Antar. Peserta Didik. Yogyakarta. Pustaka Pelajar.

Moleong, Lexy J. (2013). Metode Penelitian Kualitatif. Edisi Revisi. Bandung: PT. Remaja Rosdakarya.

Muslich, M. (2010). Text Book Writing. Jakarta: Ar-Ruzz Media

Muslih. M. (2010). Pendidikan Karakter Menjawab Tantangan Krisis Multidimensional. Jakarta: Bumi Aksara.

Purwanto. (2010). Evaluasi Hasil belajar. Yogyakarta: Pustaka Pelajar.

Roestiyah. (2001). Strategi Belajar Mengajar. Jakarta: Rineka Cipta.

Rusman. (2012). Model - Model Pembelajaran. Depok: PT Rajagrafindo Persada.

Sanjaya, W. (2010). Strategi Pembelajaran Berorientasi Standar Proses Pendidikan. Jakarta: Prenada Media Group.

Slameto. (2015). Belajar dan Faktor-Faktor yang Mempengaruhinya. Cetakan. Keenam. Jakarta: PT Rineka Cipta.

Sudjana. N. (2009). Penilaian Hasil Proses Belajar Mengajar. Bandung: PT. Remaja Rosdakarya. 
Sugiyono. (2016). Metode Penelitian Kuantitatif Kualitataif dan Kombinasi (Mixed. Methods). Bandung: Alfabeta.

Suprijono. (2013). Cooperative Learning Teori dan Aplikasi PAIKEM. Yogyakarta: Pusaka Pelajar.

Taniredja, T., and Faridli, E. M. and S. Harmianto. 2011. Model-model Pembelajaran Inovatif. Alfabeta, Bandung.

Wina. S. (2006). Strategi Pembelajaran Berorientasi Standar Proses Pendidikan. Jakarta: Kencana Prenada Media Group. 